value of various feeding stuffs under tropical conditions.

In September 1946 he returned to the Rowett Institute, and three years later became head of the Department of Applied Biochemistry. His work concerned protein and vitamin requirements, energy needs and metabolism, and mineral metabolism and requirements. He also developed chemical tests which might be correlated with the biological value of proteins. With Mr. N. W. Pirie, of Rothamsted Experimental Station, biological tests had been made on leaf protein for non-ruminants.

Duckworth was responsible, with the Institute's $X$-ray Section, for developing a mobile X-ray unit for the outdoor study of hill sheep in relation to calcium and phosphorus requirements. In his Department the role of copper in the ruminant was also under investigation, and much progress was being made in the elucidation of this problem.

In 1954, Dr. Duckworth was elected a Fellow of the Royal Society of Edinburgh, and in 1955 was one of four British scientists who attended a symposium of Europe's leading agricultural research experts in Rome, sponsored by the Pfizer Agricultural Research Institute of America, for discussion of research into the use of antibiotics and other new growth factors in animal nutrition. Later in the same year, he was one of three British experts invited to an international conference in Washington on the same subject.

From August 1956 until August 1957, he was seconded to the Food and Agriculture Organization of the United Nations and the United Nations Children's Fund, to assist the Governments of Costa Rica, El Salvador, Guatemala, Honduras, Nicaragua and Panama on food and nutrition policy. With Señorita E. Musmanno of Argentina, he collected statistics of the countries' food production, which showed that between 6 and 10 per cent of their population were dependent on outside sources of food supply. If one took into account the rate of growth of the population, it appeared to be necessary to double food production in the next twenty-five years, and to alter the balance between cereal and livestock production in favour of the latter. Due account was taken of the actual situation in the area : for example, cattle and sheep raising was to be based on native stock feeding on grass, rather than on imported stock eating concentrate feeding stuffs, at least in the early stages. The need was stressed for modern factories for milk and meat products. Almost his last task was to check the Spanish edition of their second report on the area.

Dr. Duckworth was an enterprising yet meticulous experimenter, a skilled statistician and planner, an arresting and clear expositor of his researches, and one who knew the agricultural industry as few others. $\mathrm{He}$ was a lively conversationalist and good pianist. $\mathrm{He}$ is survived by his wife, and a son and daughter.

D. P. Cuthbertson

\section{Prof. K. W. Szarski}

THE death of Prof. Kasmierz Witalis Szarski on January 18 prematurely severed a life of great service to zoology and Polish universities. He was born in Vienna in 1904 and on the family's removal to Lwöw attended school and the University there. He took his doctorate, and seven years later (1939) became docent in comparative anatomy. Soon afterwards the Russians occupied the University and demoted the staff. Later, under Nazism, academic work ceased, but by acting as hosts for lice used in preparing Prof. Weigl's anti-typhus vaceine, Szarski and colleagues slightly eased impoverishment and received certification as persons usefully employed. Afterwards he and his wife were arrested in Warsaw, but by mere chance escaped transportation to Nazi concentration camps and secured release, he being directed to vitamin investigations.

When war ended, Szarski became professor of comparative anatomy at Wroctaw, the new setting for the University of Lwöw--Polish no longer. Amid the devastation of Wroclaw half the zoological instituie lay ruined and in its and the University's rehabilitation Szarski played a leading part, particularly as pro-rector and rector (1954-59).

Szarski was a borm naturalist. His early researches related principally to developmental anatomy: three long papers on the urogenital systems of mice being authoritative. His post-war work mainly comprised ornithology and translation. His account of the birds adopting residential niches in the mountainous ruins of Wroclaw is fascinating. Freed from rectorial labours, he turned eagerly to study the avian brain-promising work cut short by his death. His comprehensive learning in zoology and his command of Slav and European languages-especially English, French and German, fitted him perfectly as counsellor, editor and translator in many professional capacities. His notable translations, with scholarly commentaries, comprise Darwin's "Voyage of the Beagle" (two editions) and Darwin's and Wallace's historic essays on natural selection (Linnaean Society of London). He was deservedly honoured when chosen to deliver the Darwin Centenary Lecture to the 1959 Polish Zoological Congress in Cracowpractically his last service to science.

Szarski was small and delicate-looking; of great culture, wit, sensitivity and charm; unpretentious ; of highest integrity, with an over-riding sense of duty that over-taxed his strength. He had courage : during the Warsaw rising a young insurgent refugee to Szarski's lodging owed his life to Szarski's bluffing of a Luftwaffe search-party. He won friendship everywhere: his students and colleagues speak of him as truly 'nieodzalowany' (never to be sufficiently mourned).

Two recent working visits to England gave Szarski renewed inspiration; in Poland British zoologists have profited by his collaboration and enjoyed the bright hospitality of Pani Szarski, himself, and their young daughter, in their modest flat high above the Oder.

In preparing this notice I am indebted to Mr. W. Rybotychi of London, Prof. Sembrat of Wroclaw and Prof. Henryk Szarski, rector of the University of Torun.

A. D. Peacock

\section{Prof. Ramesh Chandra Ray}

Ramesh Chandra Ray was born in 1890 and took the degree of M.Sc. from the Presidency College, Calcutta, in 1911. He was one of the first students of the Indian Institute of Science, Bangalore, where he worked with Travers on boron compounds formed by the decomposition of magnesium boride. In 1915 he was appointed professor of chemistry at Patna. Colloge and, after the War, joined Donnan's laboratory at University College, London, where he 
continued his work on boron compounds. He succeeded in preparing borohydrates and in establishing the existence of hitherto unknown oxides of boron. For his work on this complicated system he was awarded the D.Sc. of the University of London. He also obtained the fellowship of the Royal Institute of Chemistry.

Returning to Patna, he was responsible for creating a school of research which produced a steady output of papers on inorganic chemistry. The majority of these dealt with boron compounds and formed a valuable contribution to the chemistry of that element. In 1940 he was appointed head of the Department of Chemistry, and in all he worked for thirty-five years at the College. His outside interests were extensive, even after retirement; he was chemical adviser to the Government of Bihar, chairman of the examination board of Bihar Univer. sity, founder-rector of the Ram Mohun Roy Institute and president of the Manorma Vidyapith. In 1944 he was elected president of the Chemistry Section of the Indian Science Congress.

$\mathrm{He}$ died on December 3 and leaves a widow, four sons and three daughters.

\section{NEWS and VIEWS}

\section{Electrical Engineering at Cambridge :}

Prof. E. B. Moullin

Prof. E. B. Mouluin retires from the chair of electrical engineering at Cambridge on September 30. Thus will end his official connexion with the Engineering Laboratory, which he first entered in 1913. In that year he began to read for the Mechanical Sciences Tripos, having previously taken Part $I$ of the Mathematical Tripos. After a short period in industry, Moullin returned to a lectureship in engineering at Cambridge which he held until 1929. It was during this period that he developed the valve voltmeter associated with his name, and earried out numerous researches in collaboration with L. B. Turner. In 1930 he migrated to Oxford where he held the Donald Pollock readership in engineering science until 1945. Here, his scientific approach to electrical engineering problems attracted numerous research students, several of whom have since achieved world-wide recognition. Moullin was elected to a fellowship at Magdalen in 1932. During the Second World War he worked first at the Admiralty Signals Establishment and later in the research laboratories of Metropolitan-Vickers. In 1945 he returned to Cambridge as the first occupant of the newly created chair of electrical engineering and was elected to a fellowship at King's College. For many years Moullin has taken an active part in the affairs of the Institution of Electrical Engineers. $\mathrm{He}$ was chairman of the Radio Section in 1939 and president of the Institution in 1949. He is the author of a number of successful text-books which are distinguished by a freshness and individuality of outlook. His scientific writings cover a wide range of subjects but are largely concerned with problems in electromagnetic theory. The honorary degree of LL.D. was conferred on him by the University of Glasgow in 1958.

\section{Prof. C. W. Oatley}

C. W. OAtuey, who succeeds Prof. Moullin in the chair of Flectrical Engineering at Cambridge on October 1, was educated at Bedford Modern School and St. John's College, Cambridge. He read both parts of the Natural Sciences Tripos, specializing in physics, and graduated in 1925. After a short spell in the radio-valve industry he was appointed to a demonstratorship in the Physics Department of King's College, London, where he worked under Sir Edward Appleton and later under Sir Charles Ellis, until the outbreak of war. During this period his interests were centred on various problems of electron physics, particularly those concerned with the measurement and interpretation of the contact potential difference between metals. In 1939, Oatley joined the Air Defence Experimental Estab. lishment of the Ministry of Supply, then situated at Christchureh. There he took eharge of a group working on radar receivers and became especially interested in ultra-high frequency and microwave measurements. In 1942, when the Establishment moved to Malvern and became the Radar Research and Development Establishment, Oatley was respon. sible for all basic research work. A year later he became deputy to the Chief Superintendent and, during 1944-45, was in charge of all technical work in the Establishment. In 1945 he returned to Cambridge with a lectureship in the Department of Engineering and a fellowship at Trinity College. During the past fifteen years he has been active in building up research work in electronics and has become interested in problems of electron microscopy. He was appointed to a readership in 1954. Since the War he has had close connexion with the work of the Institution of Electrical Engineers. $\mathrm{He}$ served on the Radio Section Committee for a number of years and was chairman of the Section in 1954.

Chemistry at Aberystwyth: Prof. C. W. Davies

Prof. C. W. DAvies, who is retiring from the chair of chemistry in the University College of Wales, Aberystwyth, is well known for his many contributions to electrochemistry extending over an active research career of more than thirty years. Prof. Davies early became interested in the conductivity of electrolytes, and at the appearance of the DebyeHückel theory he was among the first to suggest the combination of the law of mass action with the ionic interaction theory to account for the conductivity of strong electrolytes. He showed that the dependence on concentration of the conductivity of many electrolytes could be accounted for if they were incompletely dissociated in solution. This conclusion was not at first readily accepted, because to many chemists the Debye-Hückel theory implied complete dissociation of all electrolytes. The idea that salts are completely dissociated in solution, and that variations in conductivity are due to variations in mobility, was too simple and attractive to be readily abandoned. This difficulty of acceptance was increased by the fact that the physical interpretation of incomplete dissociation was rather obscure. However, Prof. Davies and his collaborators showed that measurements of conductivity and of solubility led to results for dissociation constants of salts in good agreement with one another. Kinetic studies, too, have given 